\title{
Attenuated measles virus overcomes radio- and chemoresistance in human breast cancer cells by inhibiting the non-homologous end joining pathway
}

\author{
BEN YANG $^{1 *}$, JINGWEI SHI $^{2 *}$, ZHI SUN ${ }^{1}$, DONGDONG ZHU ${ }^{3}$ and XUESONG XU ${ }^{1}$ \\ Departments of ${ }^{1}$ Clinical Laboratory, ${ }^{2}$ Ophthalmology and ${ }^{3}$ Otolaryngology, Head and Neck Surgery, \\ China-Japan Union Hospital of Jilin University, Changchun, Jilin 130028, P.R. China
}

Received November 28, 2019; Accepted August 13, 2020

DOI: $10.3892 / o r .2020 .7768$

\begin{abstract}
Breast cancer is the most commonly diagnosed cancer and is the second leading cause of death in women. However, resistance to radio- and chemotherapy remains one of the major difficulties in the treatment of breast cancer. Therefore, the aim of the present study was to identify novel regimens to overcome treatment resistance in patients with breast cancer. The results of the present study demonstrated that the attenuated Edmonston-B vaccine strain of the measles virus (MV-Edm) significantly re-sensitized breast cancer cells to doxorubicin and ionizing radiation. Mechanistically, MV-Edm reduced DNA double strand repair efficiency by decreasing the mRNA and protein expression levels of p53-binding protein 1 and disassembling the non-homologous end joining (NHEJ) complex. NHEJ deficiency, which was achieved using DNA ligase IV knockout via CRISPR/Cas9, resulted in failure to overcome resistance mediated by MV-Edm infection. As a result of the significant synergy between attenuated $\mathrm{MV}$ and radio- or chemotherapy, $\mathrm{MV}$-Edm provides a novel strategy for the treatment of radio- and chemoresistant breast cancer.
\end{abstract}

\section{Introduction}

Measles virus (MV) is a highly contagious enveloped negativestrand RNA virus, and is the cause of a viral respiratory

Correspondence to: Dr Xuesong Xu, Department of Clinical Laboratory, China-Japan Union Hospital of Jilin University, 126 Xiantai Street, Changchun, Jilin 130028, P.R. China

E-mail: xuxsong2019@163.com

${ }^{*}$ Contributed equally

Abbreviations: MV-Edm, Edmonston-B vaccine strain of measles virus; NHEJ, non-homologous end joining; HR, homologous recombination; DSB, DNA double strand break; IR, ionizing radiation

Key words: breast cancer, measles virus, DNA repair, doxorubicin resistance, radiation resistance infection (1). By contrast, the attenuated form of MV, which has been used as a vaccine for $>60$ years (2), inhibits cancer cell proliferation (3-6). Attenuated MV have been extensively investigated in numerous clinical trials to treat various types of cancer, such as ovarian cancer (NCT02364713) (7), glioblastoma multiforme (NCT00390299) (8) and breast cancer (NCT01503177) (9); however, despite the potential of MV in cancer treatment, whether MV can induce efficient toxicity on chemo- or radioresistant cancer cells is still unknown.

Breast cancer is the most commonly diagnosed type of cancer among women, and is the second leading cause of female morbidity and mortality worldwide (10). According to the American Cancer Society, it was estimated that 271,270 new cases of breast cancer were diagnosed in the United States in 2019, which accounted for $15 \%$ of total cancer diagnoses (11). The current treatment used for breast cancer includes surgery, chemo- and radiotherapy, which has increased the survival rate over the past few decades; however, $>30 \%$ of patients with breast cancer develop resistance to treatment and eventually metastasis $(12,13)$. Therefore, it is crucial to elucidate the mechanisms of treatment resistance in breast cancer, which have not been fully elucidated. Various breast cancer chemotherapeutics, including doxorubicin, 5-fluorouracil and carboplatin, as well as radiation therapy induce cell death by causing DNA damage (14). Thus, abnormal DNA repair is one of the plausible mechanisms for both chemo- and radioresistance (15-17).

Unrepaired DNA double strand break (DSB) results in cell death, while misrepaired DSBs can cause chromosomal translocations (18). Therefore, DSB is the most important type of DNA damage that can be caused by DNA damaging agents and ionizing radiation (IR) (19). Homologous recombination (HR) and non-homologous end joining (NHEJ) are the major DSB repair pathways in mammals (20). These factors require essential factors and lead to different repair outcomes. HR is typically considered to be the 'error-free' pathway as it incorporates sister chromatids as a template to guide the repair; thus, HR is restricted to the late $\mathrm{S}$ to $\mathrm{G} 2$ phase of the cell cycle $(21,22)$. By contrast, NHEJ is active throughout the cell cycle (22). We hypothesized that MV may affect the resistance and DSB repair in breast cancer. The present study aimed to further evaluate whether MV may sensitize breast cancer cells to chemo- and radiotherapy by regulating DSB repair. 


\section{Materials and methods}

Cell lines and cell culture. MCF7 (cat. no. HTB-22 ${ }^{\mathrm{TM}}$ ) and Vero cells (cat. no. CCL- $81^{\mathrm{TM}}$ ) were cultured at $37^{\circ} \mathrm{C}$ in a humidified incubator with $5 \% \mathrm{CO}_{2}$ in Eagle's Minimum Essential Medium (cat. no. 30-2003) with 10\% FBS for $<4$ weeks. T47D (cat. no. HTB-133 ${ }^{\mathrm{TM}}$ ) cells were cultured at $37^{\circ} \mathrm{C}$ in a humidified incubator with 5\% $\mathrm{CO}_{2}$ in RPMI-1640 (cat. no. 30-2001) with 10\% FBS (all from American Tissue Culture Collection) for $<4$ weeks.

Doxorubicin-resistant (DR) MCF7 cells were generated by incubating MCF7 cells in medium with $0.25 \mu \mathrm{M}$ doxorubicin for 2 weeks, followed by 0.5 and $1 \mu \mathrm{M}$ doxorubicin for 2 weeks at each concentration. IR-resistant (IRR) MCF7 cells were generated by treating MCF7 cells with 1-Gy IR twice in one week, followed by exposure to 2-Gy IR twice a week for two weeks.

Virus propagation and infection. MV-Edm was harvested as previously described (23). Attenuated measles virus vaccines were obtained from National Biotec Group Co., Ltd., China. The virus was propagated in Vero cells (cat. no. CCL-81 ${ }^{\mathrm{TM}}$; ATCC) with an MOI 0.01 at $37^{\circ} \mathrm{C}$ for $2 \mathrm{~h}$. The medium was then replaced, and the cells were maintained at $32^{\circ} \mathrm{C}$ for virus propagation. At 3 days post-infection, the infected cells were scraped into $1 \mathrm{ml}$ Opti-MEM (cat. no. 51985091; Thermo Fisher Scientific, Inc.). The viral particles were harvested from Vero cells by snap-freezing in liquid nitrogen and thawing in a water bath at $37^{\circ} \mathrm{C}$ for 5 cycles. A $50 \%$ tissue culture infective dose titer was calculated from the $50 \%$ endpoint dilution assay in Vero cells (24). Viral infection was performed as previously described (25). Briefly, MCF7 and T47D cells were seeded at a density of $3 \times 10^{5}$ cells/well in triplicate in 6-well plates with $2 \mathrm{ml}$ complete media. After $24 \mathrm{~h}$, the cells were incubated with $0-0.5 \mathrm{MOI}$ virus for $24 \mathrm{~h}$ at $37^{\circ} \mathrm{C}$. The cells were trypsinized and harvested for further experiments.

Analysis of cell viability. MCF7 and T47D cells were seeded at a density of $5 \times 10^{3}$ cells/well in triplicate in 96 -well plates with $100 \mu \mathrm{l}$ complete media. After $24 \mathrm{~h}$ at $37^{\circ} \mathrm{C}$, the cells were treated with doxorubicin for $48 \mathrm{~h}$ at $37^{\circ} \mathrm{C}$, and the cell viability was determined using MTT assay. Briefly, $10 \mu 1 \mathrm{MTT}$ (Sigma-Aldrich; Merck KGaA) solution was added to each well, and the plates were incubated for $3 \mathrm{~h}$ at $37^{\circ} \mathrm{C}$. DMSO was subsequently added to each well (100 $\mu \mathrm{l} /$ well) to dissolve the formazan crystals, and the absorbance was measured at $490 \mathrm{~nm}$ using an Epoch ${ }^{\mathrm{TM}} 2$ Microplate spectrophotometer (BioTek Instruments, Inc.).

NHEJ and HR efficiency assay. A total of $10 \mu \mathrm{g}$ of NHEJ or HR reporter plasmid was linearized using NheI and purified using the QIAquick Gel Extraction kit (cat. no. 28704; Qiagen, Inc.) according to the manufacturer's instructions. The purified plasmid $(1 \mu \mathrm{g})$ was transfected into MCF7 and T47D cells $\left(3 \times 10^{5}\right.$ cells $\left./ \mathrm{ml} ; 2 \mathrm{ml}\right)$ using Lipofectamine ${ }^{\circledR} 3,000$ (cat. no. L3000015; Invitrogen; Thermo Fisher Scientific, Inc.) according to the manufacturer's protocol and incubated at $37^{\circ} \mathrm{C}$ for $48 \mathrm{~h}$. Stably transfected cells were selected by incubating in medium with $1 \mathrm{mg} / \mathrm{ml}$ geneticin for 2 weeks and subsequently stored in liquid nitrogen until further use. To measure NHEJ efficiency, stably transfected cells were seeded at $3 \times 10^{5}$ cells $/ \mathrm{ml}$ in a 6-well plate and cultured for $24 \mathrm{~h}$. For the NHEJ or HR assay, $2 \mu \mathrm{g}$ I-SceI plasmid (cat. no. 26477; Addgene, Inc.) was transfected into MCF7 and T47D cells $\left(3 \times 10^{5}\right.$ cells $\left./ \mathrm{ml} ; 2 \mathrm{ml}\right)$ using Lipofectamine ${ }^{\circledR} 3,000$ to recognize the I-SceI restriction enzyme site and generate DSB. After incubation at $37^{\circ} \mathrm{C}$ for $48 \mathrm{~h}$, positive cells expressing green fluorescent protein (GFP), which indicated successful DSB repair, were measured using a FACSCelesta flow cytometer (BD Biosciences) and analyzed using FlowJo software (V.10; FlowJo, LLC).

Reverse transcription-quantitative PCR (RT- $q P C R)$. RNA was extracted from MCF7 and T47D cells using the RNeasy Mini Kit (cat.no. 74104; Qiagen $\mathrm{GmbH}$ ) and was reverse-transcribed using the iScript ${ }^{\mathrm{TM}}$ RT Supermix (Bio-Rad Laboratories, Inc.) according to the manufacturer's instructions. Subsequently the $\mathrm{iQ}^{\mathrm{TM}} \mathrm{SYBR}^{\circledR}$ Green Supermix (Bio-Rad Laboratories, Inc.) was used for qPCR to detect the mRNA levels of the NHEJ factors according to the manufacturer's instructions using a Real-Time PCR system (Eppendorf Thermal Cycler Eco; Eppendorf) (26). The thermocycling conditions included initial denaturation at $95^{\circ} \mathrm{C}$ for $3 \mathrm{~min}$, followed by 35 cycles of denaturation at $95^{\circ} \mathrm{C}$ for $10 \mathrm{sec}$ and annealing and extension at $60^{\circ} \mathrm{C}$ for $50 \mathrm{sec}$. The relative expression levels were quantified using the $2^{-\triangle \Delta C q}$ method (27).

The following primers were used: $\beta$-actin forward, 5'-ACCAACTGGGACGACATGGAG-3' and reverse, 5'-GTG AGGATCTTCATGAGGTAGTC-3'; $70 \mathrm{kDa}$ subunit of Ku antigen (Ku70) forward, 5'-ATGGCAACTCCAGAGCAG GTG-3' and reverse, 5'-AGTGCTTGGTGAGGGCTTCCA-3'; $86 \mathrm{kDa}$ subunit of $\mathrm{Ku}$ antigen (Ku80) forward, 5'-TGACTT CCTGGATGCACTAATCGT-3' and reverse, 5'-TTGGAG CCAATGGTCAGTCG-3'; catalytic subunit of a nuclear DNA-dependent serine/threonine protein kinase (DNA-PKcs) forward, 5'-CCAAGTCCA ACACCAAGTAGCCACCCA-3' and reverse, 5'-CCGCCATGCCGCCGAGTCCC-3'; X-ray repair cross-complementing 4 (XRCC4) forward, 5'-CCC TCACAGAAACACAACTCA-3' and reverse, 5'-CAAGGA GGTGGCCACTAGTT-3; XRCC4-like factor (XLF) forward, 5'-ACAAGGTCTAATGCACCCCA-3' and reverse, 5'-GGG TTGCAGCCTTAGAAAAGT-3'; DNA ligase IV forward, 5'-CACCTTGCGTTTTCCACGAA-3' and reverse, 5'-CAG ATGCCTTCCCCCTAAGTTG-3'; and p53-binding protein 1 (53BP1) forward, 5'-CCAGCACCAACAAGAGC-3' and reverse, 5'-GGATGCCTGGTACTGTTTGG-3'.

Western blot analysis. MCF7 and T47D cells were pelleted and resuspend in hypotonic buffer ( $20 \mathrm{mM}$ Tris-HCl, $\mathrm{pH} 7.4,10 \mathrm{mM}$ $\mathrm{NaCl}, 3 \mathrm{mM} \mathrm{MgCl} 2$ ). The cells were lysed by adding $10 \% \mathrm{NP} 40$ and vortexing. The cell lysate was centrifuged for $15 \mathrm{~min}$ at $1,200 \times \mathrm{g}$ at $4^{\circ} \mathrm{C}$, and the supernatant (cytoplasmic fraction) was removed. The nuclear pellet was lysed in lysis buffer $(10 \mathrm{mM}$ Tris, pH 7.4, $150 \mathrm{mM} \mathrm{NaCl}, 2 \mathrm{mM}$ Na3VO4, $1 \%$ Triton X-100, $1 \mathrm{mM}$ EDTA, $0.1 \%$ SDS, $0.5 \%$ deoxycholate, $1 \mathrm{mM} \mathrm{NaF}, 10 \%$ glycerol) with $1 \mathrm{X}$ protease cocktail (Roche Diagnostics) for $30 \mathrm{~min}$ on ice with vortexing and centrifuged at $14,000 \mathrm{x} \mathrm{g}$ at $4^{\circ} \mathrm{C}$, following which the protein concentration of the supernatant (nuclear fraction) was determined using Bradford assay. The samples (20 $\mu \mathrm{g} / \mathrm{lane})$ were separated using SDS-PAGE and transferred to PVDF membranes (Roche Diagnostics). After 
blocking with $3 \%$ BSA in $1 \mathrm{X}$ PBS with $0.1 \%$ Tween-20, the membrane was incubated with primary antibodies, followed by incubation with horseradish peroxidase-conjugated secondary antibodies. The signals were detected using an enhanced chemiluminescence reagent (Thermo Fisher Scientific, Inc.), and the proteins were visualized using the ChemiDoc MP imaging system (Bio-Rad Laboratories, Inc.) and analyzed using ImageJ version 1.51 software (National Institutes of Health). The following antibodies (1:1,000 dilution) were used: Anti-Ku70 (cat. no. 4588; Cell Signaling Technology, Inc.), anti-Ku80 (Cell Signaling Technology, Inc.), anti-DNA-PKcs (cat. no. 38168; Cell Signaling Technology, Inc.), anti-XLF (cat. no. 2854; Cell Signaling Technology, Inc.), anti-XRCC4 (cat. no. sc-136124; Santa Cruz Biotechnology, Inc.), anti-DNA ligase IV (cat. no. 14649; Cell Signaling Technology, Inc.), anti-53BP1 (cat. no. 4937; Cell Signaling Technology, Inc.), anti-lamin B1 (cat. no. 65986; Abcam) and anti-origin recognition complex subunit 2 (ORC2; cat. no. 4736; Cell Signaling Technology, Inc.).

Chromatin fractionation assay. DNA damage was induced using 2-Gy of IR or $0.5 \mu \mathrm{M}$ doxorubicin, and the cells were allowed to recover for $2 \mathrm{~h}$ to allow the DNA repair mechanism to assemble. Subsequently, MCF7 cells were lysed in buffer A (50 mM HEPES-KOH, pH 8.0, 150 mM NaCl, 10\% glycerol, $3 \mathrm{mM} \mathrm{MgCl}_{2}, 1 \mathrm{mM}$ EGTA, 1\% NP-40, $1 \mathrm{mM}$ DTT) with $1 \mathrm{X}$ protease inhibitor cocktail (Roche Diagnostics) on ice for $20 \mathrm{~min}$ and centrifuged at $1,200 \mathrm{x} \mathrm{g}$ at $4^{\circ} \mathrm{C}$ for $3 \mathrm{~min}$. The cell pellets were collected and lysed in buffer B $(10 \mathrm{mM}$ Tris-HCl, $200 \mathrm{mM} \mathrm{NaCl}, 1 \mathrm{mM}$ EDTA, 1 mM EGTA) with $1 \mathrm{X}$ protease inhibitor cocktail and centrifuged at $1,200 \mathrm{x}$ g at $4^{\circ} \mathrm{C}$ for $3 \mathrm{~min}$. The sediment was resuspended in buffer $\mathrm{C}(50 \mathrm{mM}$ Tris- $\mathrm{HCl}, \mathrm{pH} 8,20 \mathrm{mM} \mathrm{NaCl}, 1 \mathrm{mM} \mathrm{MgCl} \mathrm{m}_{2}, 0.1 \%$ SDS, $1 \%$ NP-40) supplemented with $1 \mathrm{X}$ protease inhibitor cocktail and denatured with SDS loading buffer.

DNA pull-down assay. A 50\% DNA cellulose (Invitrogen; Thermo Fisher Scientific, Inc.) mixture was washed in washing buffer [50 mM HEPES, pH 8, $100 \mathrm{mM}$ potassium acetate, $0.5 \mathrm{mM}$ magnesium acetate, $1 \mathrm{mM}$ ATP, $1 \mathrm{mM}$ DTT, $0.1 \mathrm{mg} / \mathrm{ml}$ bovine serum albumin (Sigma-Aldrich; Merck KGaA)] three times. MCF7 and T47D cells $\left(3 \times 10^{5}\right.$ cells $\left./ \mathrm{ml} ; 2 \mathrm{ml}\right)$ were cultured in the presence or absence of 0.5 multiplicity of infection (MOI) MV-Edm for $24 \mathrm{~h}$ and lysed using RIPA buffer (150 mM NaCl, $1 \% \mathrm{NP}-40,0.5 \%$ sodium deoxycholate, $0.1 \%$ SDS, $25 \mathrm{mM}$ Tris, $\mathrm{pH}$ 7.4) supplemented with $1 \mathrm{X}$ protease inhibitor cocktail. The 53BP1 protein was immunoprecipitated from the cell extract using an anti-53BP1 antibody (cat. no. 4937; Cell Signaling Technology, Inc.) followed by A/G protein binding beads (Thermo Fisher Scientific, Inc.). A total of $0.1 \mu \mathrm{g}$ 53BP1 was added to $20 \mu \mathrm{l}$ of the DNA cellulose mixture. The reactions were rotated at room temperature for $3 \mathrm{~h}$, and the DNA cellulose was centrifuged at 1,000 $\mathrm{x} g$ for $1 \mathrm{~min}$ and was washed twice with washing buffer. The pellet was resuspended in $20 \mu 1$ 2X SDS buffer, and DNA-bound 53BP1 was analyzed using western blot analysis. The non-biotinylated DNA-bound 53BP1 was used as negative control.

CRISPR-Cas9-mediated DNA ligase IV deletion. A pool of 3 plasmids, each encoding the Cas9 coding gene and ligase IV-specific 20 nt guide RNA (cat. no. sc-401372; Santa Cruz
Biotechnology, Inc.), targeting the 5' constitutive exon within the ligase IV gene, was transfected into MCF7-DR and MCF7-IRR cells using Lipofectamine ${ }^{\circledR} 3,000$ and selected as previously described (28). Cells were trypsinized and seeded in 96-well plate at densities of 100, 300 and 500 cells $/ \mathrm{ml}$ and incubated for 14 days at $37^{\circ} \mathrm{C}$. Single clones were selected, expanded and screened for DNA ligase IV expression using western blot analysis (29). The CRISPR/Cas9-Ctr plasmid (cat. no. sc-418922; Santa Crus Biotechnology, Inc.), which encoded a single scrambled gRNA sequence, was used as negative control. For each knockout, two clones (KO1 and $\mathrm{KO} 2$ ) were selected for further experiments.

Caspase-3/7 activity assay. Caspase-3/7 activity was measured using the Caspase-Glo ${ }^{\circledR}$ 3/7 Assay System according to the manufacturer's protocol (Promega Corporation). MCF7-IRR, MCF7-DR, T47D-IRR and T47D-DR cells $\left(1 \times 10^{4}\right.$ cells/well in 96-well plate) were treated with MV-Edm for $24 \mathrm{~h}$, followed by exposure to 2-Gy IR or $0.1 \mu \mathrm{M}$ doxorubicin. Subsequently, $100 \mu \mathrm{l}$ Caspase-Glo ${ }^{\circledR}$ 3/7 reagent was added in each well and gently mixed with the cells, and incubated at room temperature for $1.5 \mathrm{~h}$ before caspase-3/7 activity was measured using a luminometer (490 nm excitation, $570 \mathrm{~nm}$ emission) (FLUOstar Optima).

Statistical analysis. Data are presented as the mean \pm standard error of the mean from three experimental repeats. GraphPad Prism v7.0 software (GraphPad Software, Inc.) was used to plot the graphs and analyze the data. Student's t-test was used for comparisons between two groups. One-way or two-way ANOVA with the Bonferroni post hoc test was used to compare multiple groups. $\mathrm{P}<0.05$ was considered to indicate a statistically significant difference.

\section{Results}

MV impairs NHEJ efficiency in breast cancer cells. To determine the cell viability inhibition induced by MV-Edm, the MCF7 and T47D cell lines were infected with 0, 0.1 and 0.5 MOI MV-Edm. As presented in Fig. 1A and B, the viral infection significantly inhibited the viability of the two breast cancer cell lines compared with that of uninfected cells.

To investigate which DSB repair pathway was affected by MV, MCF7 and T47D cells were treated with MV-Edm and analyzed using NHEJ and HR efficiency assays. These reporter assays integrate inducible DSB in chromosomal DNA, and the successful repair of DSB results in GFP expression. NHEJ and HR efficiency was measured using flow cytometry, and the results revealed that $0.5 \mathrm{MOI}$ MV-Edm decreased NHEJ efficiency to $\sim 30 \%$ of that observed in control groups in the MCF7 and T47D cell lines (Fig. 1C and D). The viral infection increased HR efficiency by 10-20\% compared with the respective control groups (Fig. 1E and F). These results suggested that impaired NHEJ may be a mechanism of inhibition of cell viability induced by MV-Edm in breast cancer cells.

$M V$ decreases 53BP1 mRNA expression levels in breast cancer cells. To elucidate how MV-Edm affected NHEJ efficiency, the mRNA expression levels of NHEJ-associated factors were investigated, including Ku70, Ku80, DNA-PKcs, XRCC4 and XLF, as well as the pathway factor 53BP1, which 

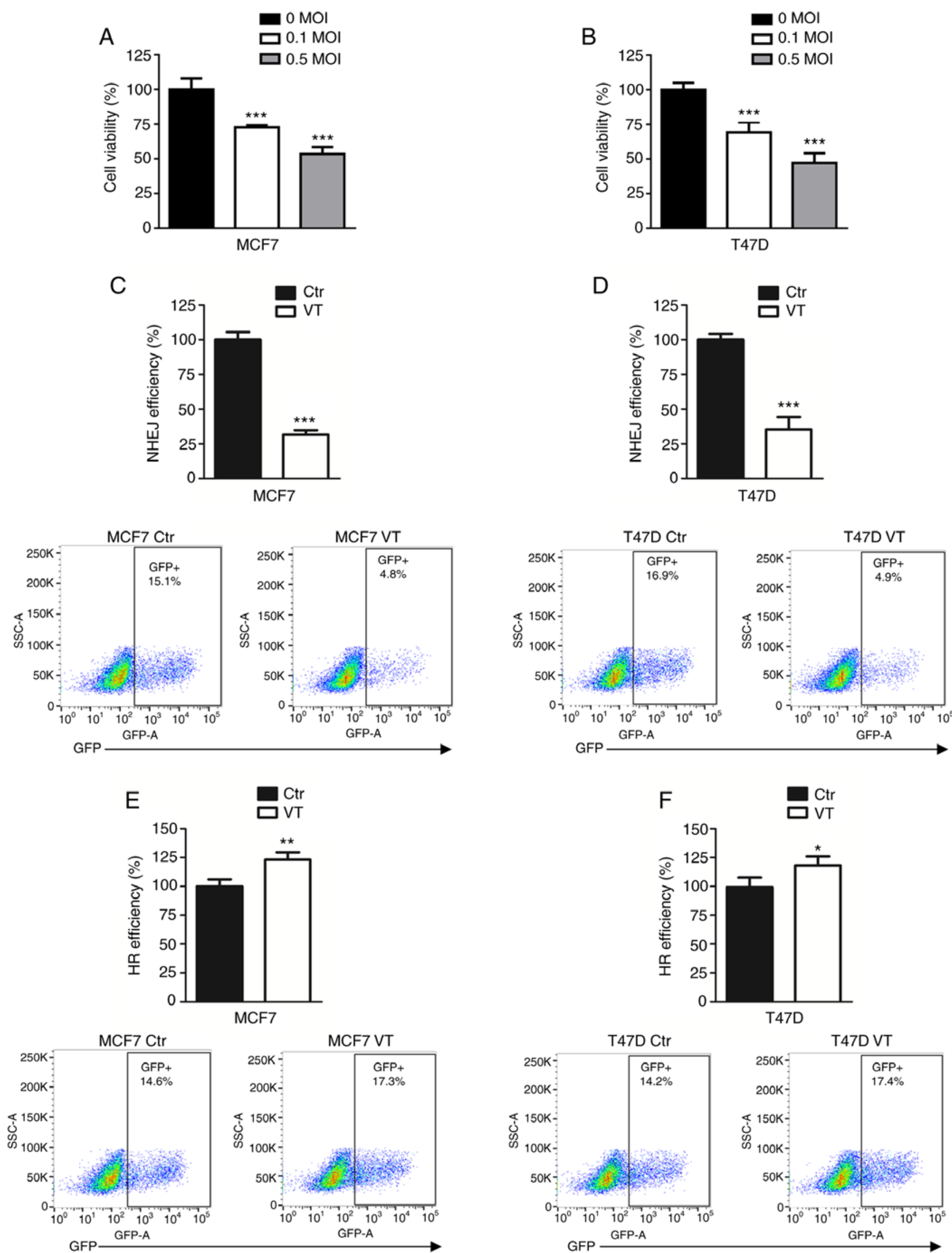

Figure 1. MV impairs NHEJ efficiency in breast cancer cells. (A and B) MV-Edm at an MOI of 0, 0.1 or 0.5 inhibited (A) MCF7 and (B) T47D cell viability as determined by MTT assay. ${ }^{* * *} \mathrm{P}<0.001$ vs. 0 MOI. (C and D) Quantification of GFP generated by NHEJ in (C) MCF7 and (D) T47D cells treated with vehicle or 0.5 MOI VT. The GFP level was normalized to that of cells treated with the vehicle. ${ }^{* * *} \mathrm{P}<0.001$ vs. Ctr. (E and F) Quantification of GFP generated by homologous recombination in (E) MCF7 and (F) T47D cells treated with vehicle or 0.5 MOI VT. The GFP level was normalized to that of cells treated with the vehicle. ${ }^{*} \mathrm{P}<0.05$ and ${ }^{* *} \mathrm{P}<0.01$ vs. Ctr. MOI, multiplicity of infection; GFP, green fluorescent protein; VT, virus transfection, MV, measles virus; Edm, Edmonston-B. 

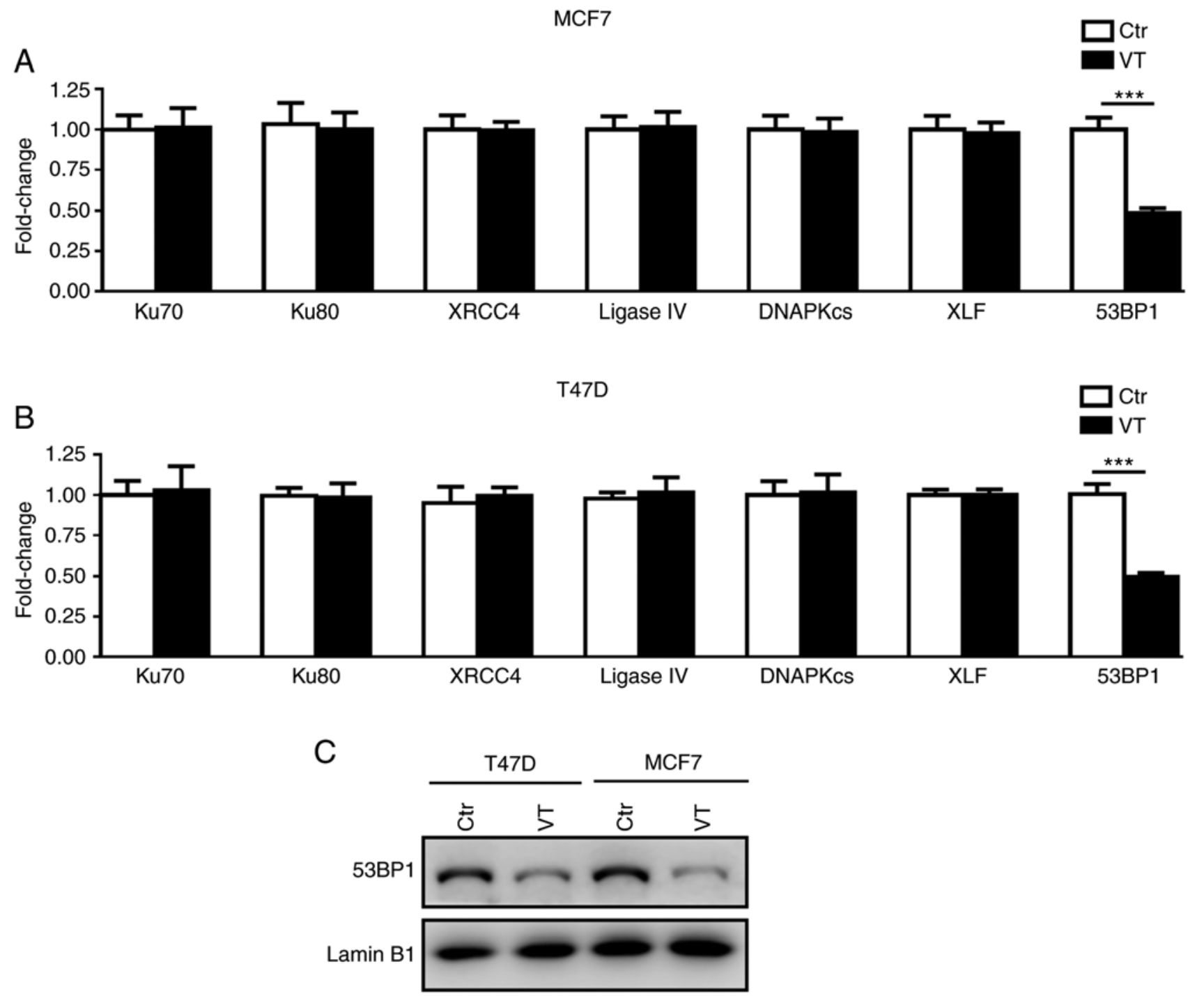

Figure 2. MV decreases the mRNA expression levels of 53BP1 in breast cancer cells. (A and B) The mRNA expression levels of Ku70, Ku80, XRCC4, ligase IV, DNA-PKcs, XLF and 53BP1 in (A) MCF7 and (B) T47D cells infected with 0.5 MOI MV-Edm for $24 \mathrm{~h}$ were determined using quantitative PCR. ${ }^{* * *} \mathrm{P}<0.001$. (C) Western blot analysis of 53BP1 expression following infection with $0.5 \mathrm{MOI}$ MV-Edm for $24 \mathrm{~h}$. $\beta$-actin was used as the internal control. MV, measles virus; VT, virus transfection; Edm, Edmonston-B; MOI, multiplicity of infection; DNA-PKcs, DNA-dependent protein kinase catalytic subunit; XRCC4, X-ray repair cross-complementing 4; XLF, XRCC4-like factor; 53BP1, p53-binding protein 1.

favors NHEJ (30). In both breast cancer cell lines, 0.5 MOI MV-Edm reduced the mRNA expression levels of 53BP1, but not those of other NHEJ factors (Fig. 2A and B). Western blot analysis demonstrated that the protein expression level of 53BP1 was decreased in MV-Edm-infected T47D and MCF7 cells (Fig. 2C), indicating that MV-Edm may impair NHEJ efficiency by downregulating 53BP1.

$M V$-Edm inhibits the assembly of NHEJ factors. Impaired 53BP1 mRNA and protein expression by MV-Edm infection results in decreased NHEJ efficiency, which may be due to the activation of an unfavored pathway. To determine whether MV-Edm impedes the NHEJ pathway in cells, in which NHEJ was previously incorporated for DSB repair, DNA damage was induced using 2-Gy IR, and the cells were allowed to recover for $2 \mathrm{~h}$ to allow the DNA repair mechanism to assemble. The chromatin binding activity of the NHEJ-associated factors was determined using a chromatin fractionation assay, and the results demonstrated that 0.5 MOI MV-Edm treated cells exhibited a notable decrease in chromatin binding of DNA-PKcs, XRCC4, XLF and ligase IV in MCF7 cells compared with that in the control cells (Fig. 3A). A similar result was also observed in doxorubicin-treated MCF7 cells (Fig. 3B).

To determine whether MV-Edm affected the DNA binding activity of 53BP1, biotinylated DNA was used to pull down the 53BP1 immunoprecipitate from MV-Edm-infected and control cells. As presented in Fig. 3C and D, MV-Edm did not affect the 53BP1-DNA interaction in MCF7 cells after IR and doxorubicin treatment. These observations suggested that MV-Edm may induce NHEJ defects in breast cancer cells by reducing NHEJ incorporation during DSB repair by downregulating 53BP1, as well as disrupting the NHEJ protein complex during NHEJ.

Combination of $M V$ and IR/doxorubicin overcomes radioand chemoresistance in breast cancer cells. As abnormal DNA repair contributes to radio- and chemoresistance in various types of cancer, we hypothesized that MV-Edm, which significantly impairs NHEJ in breast cancer cells, may inhibit 
A
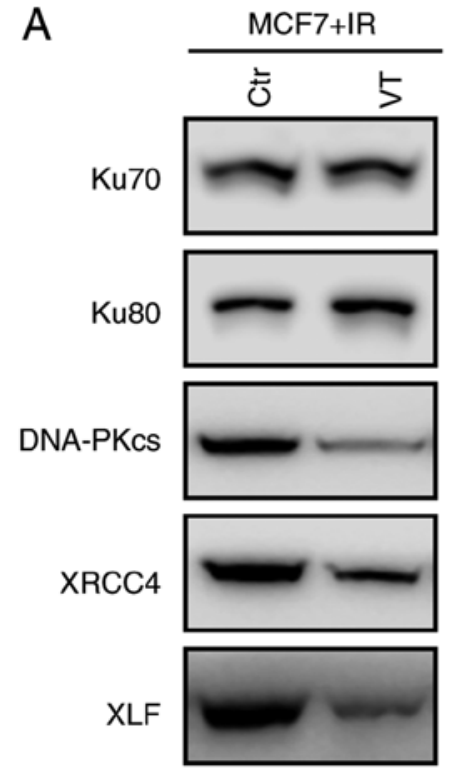

Ligase IV

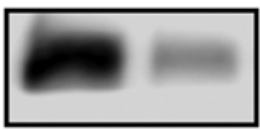

ORC2

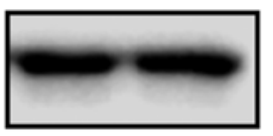

C

MCF7+IR

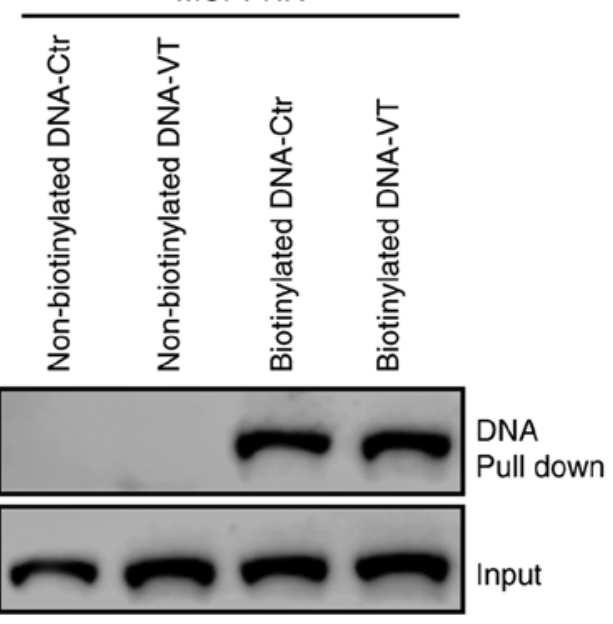

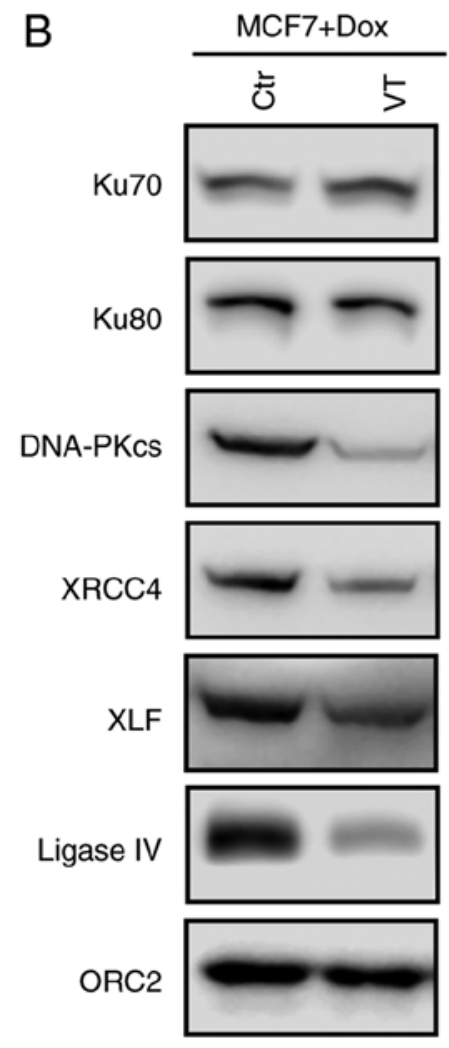

D

MCF7+Dox

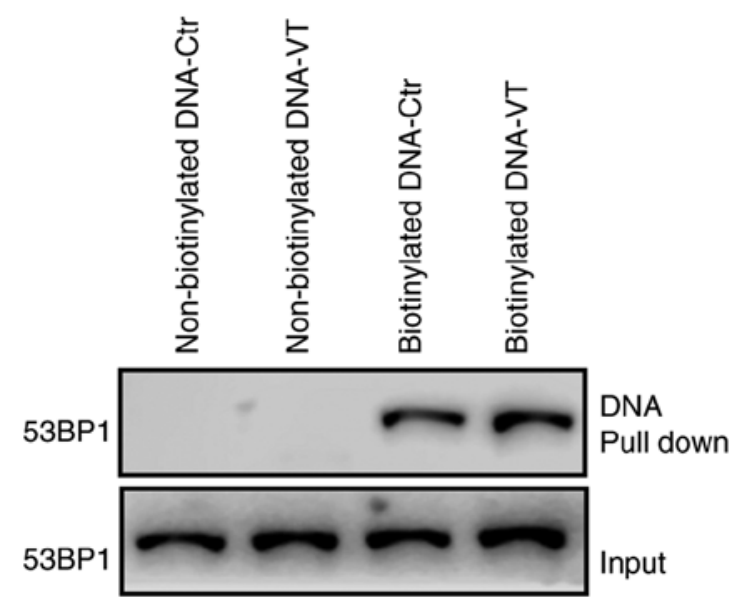

Figure 3. MV inhibits the assembly of NHEJ factors. (A and B) Chromatin assembly of NHEJ key factors in MCF7 cells. Chromatin-bound proteins were detected using western blotting analysis in cells infected with $0.5 \mathrm{MOI}$ MV-Edm for $24 \mathrm{~h}$ followed by (A) 2-Gy IR or (B) $0.5 \mu \mathrm{M}$ doxorubicin treatment. ORC2 was used as an internal control. (C and D) DNA pull-down assay for 53BP1 in (C) IR- or doxorubicin-treated MCF7 cells infected with 0.5 MOI MV-Edm for $24 \mathrm{~h}$. MV, measles virus; NHEJ, non-homologous end joining; MOI, multiplicity of infection; VT, virus transfection; Edm, Edmonston-B; IR, ionizing radiation; DNA-PKcs, DNA-dependent protein kinase catalytic subunit; XRCC4, X-ray repair cross-complementing 4; XLF, XRCC4-like factor; 53BP1, p53-binding protein 1.

cell viability in treatment-resistant cells. First, MCF7-IRR, T47D-IRR, MCF7-DR and T47D-DR cell lines were established (Fig. S1). Cells resistant to IR or doxorubicin exhibited a $\sim 40-60 \%$ increase in NHEJ efficiency compared with that in the respective parental cells $(\mathrm{P}<0.001$; Fig. S2).

To determine whether MV-Edm affected NHEJ efficiency in resistant cell lines, the IRR and DR cell lines were infected with 0.5 MOI MV-Edm, and the NHEJ efficiency compared with that in the control cells was investigated. As presented in
Fig. 4A-D, MV-Edm significantly decreased NHEJ efficiency in the IRR and DR cell lines. Subsequently, cell viability was measured in the resistant cell lines infected with MV-Edm following IR or doxorubicin treatment. The results demonstrated that MV-Edm significantly inhibited cell viability in MCF7-IRR cells; in particular, 0.5 MOI MV-Edm decreased cell survival by 4.36 -fold at 2 Gy (Fig. 4E) compared with 0 MOI MV-Edm treatment. In addition, MCF7-DR cells were re-sensitized to doxorubicin by MV-Edm infection, and cell 
A
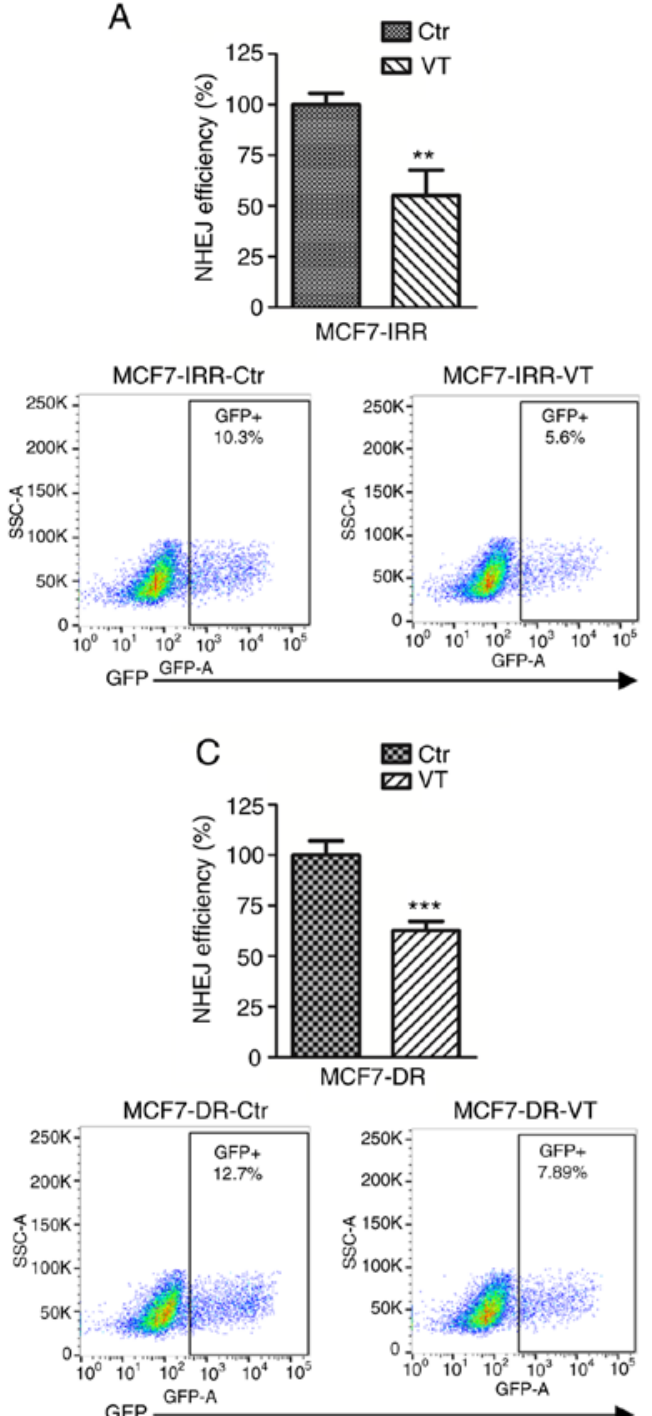

E
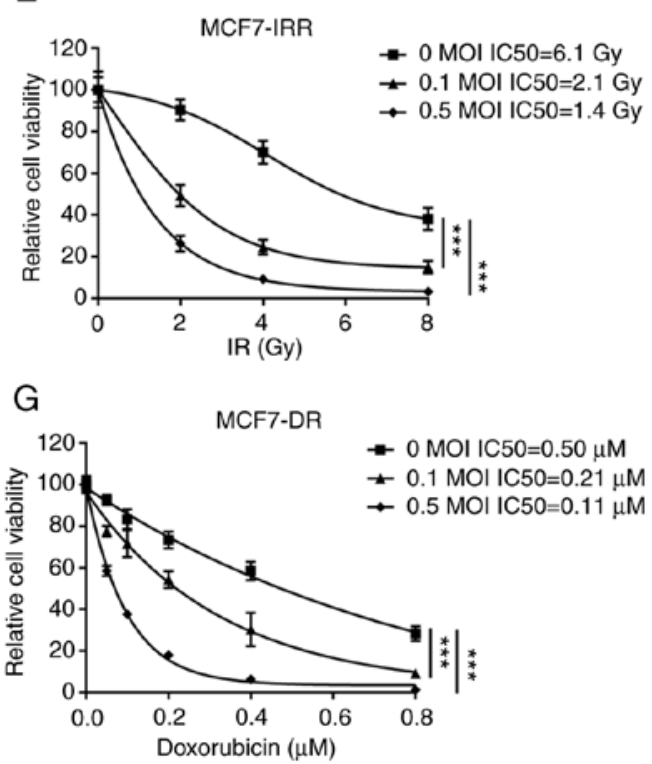

B
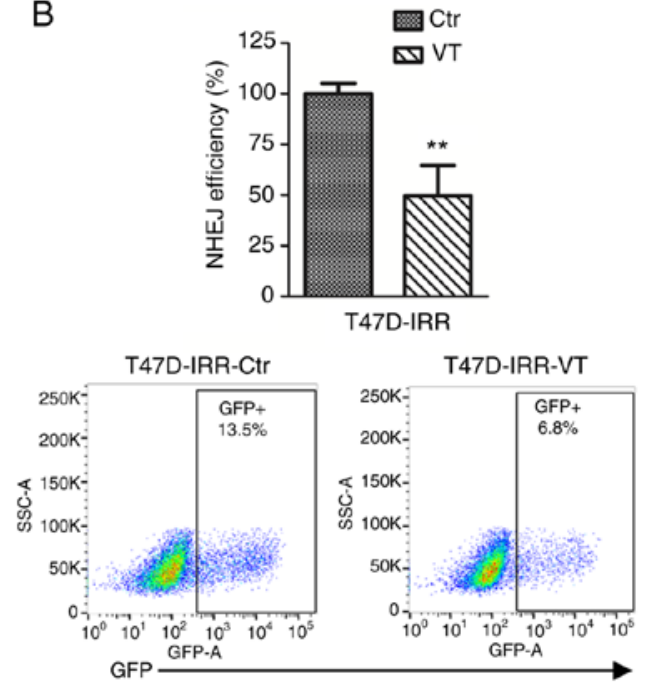

$\mathrm{D} \quad \mathrm{B} \mathrm{B}$ (tr

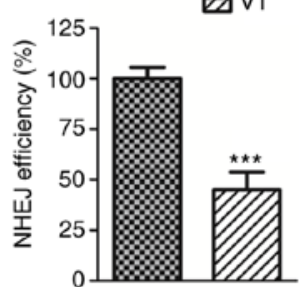

T47D-DR

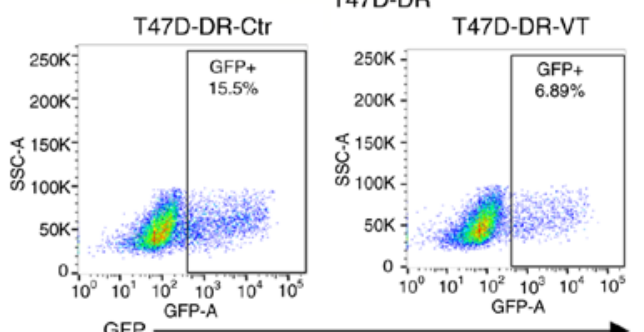

F

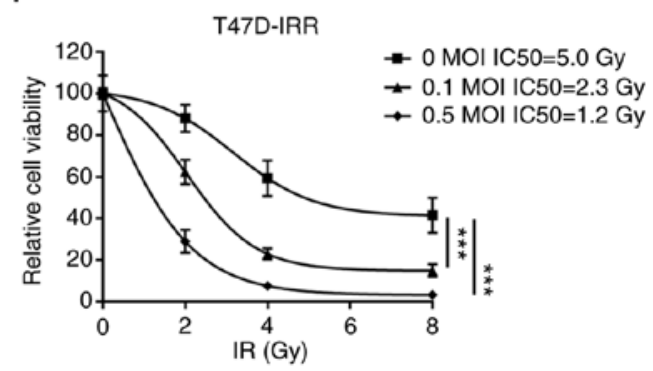

$\mathrm{H}$

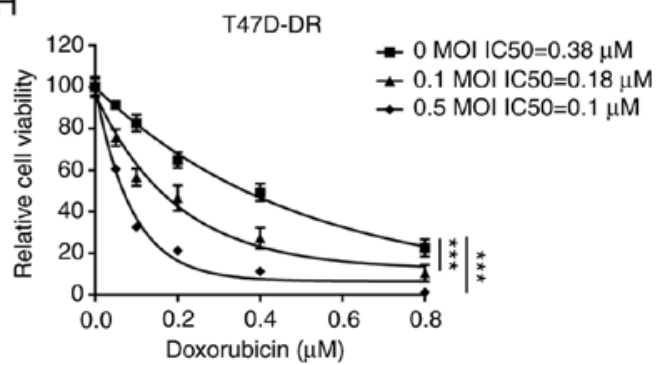

Figure 4. Combination of MV and IR/doxorubicin overcomes radio- and chemoresistance in breast cancer cells. (A-D) Quantification of GFP generated by NHEJ in (A) MCF7-IRR, (B) T47D-IRR, (C) MCF7-DR and (D) T47D-DR cells treated with vehicle or 0.5 MOI virus transfection. The GFP level was normalized to that of cells treated with the vehicle. ${ }^{* *} \mathrm{P}<0.01$ and ${ }^{* * *} \mathrm{P}<0.001$ vs. Ctr. (E and F) MV-Edm re-sensitized (E) MCF7-IRR and (F) T47D-IRR cells to IR. Cell viability was evaluated using MTT assay following infection with MV-Edm at a MOI of $0,0.1$ or 0.5 and IR treatment. ${ }^{* * *} \mathrm{P}<0.001$. (G and $\left.\mathrm{H}\right) \mathrm{MV}-\mathrm{Edm}$ re-sensitized (G) MCF7-DR and (H) T47D-DR cells to doxorubicin. Cell viability was evaluated using MTT assay. Cells were infected with MV-Edm at a MOI of $0,0.1$ or 0.5 , followed by doxorubicin treatment. ${ }^{* * *} \mathrm{P}<0.001$. GFP, green fluorescent protein; MOI, multiplicity of infection; NHEJ, non-homologous end joining; IR, ionizing radiation; DR, doxorubicin resistant; IRR, ionizing radiation resistant; MV, measles virus; Edm, Edmonston-B. 
A
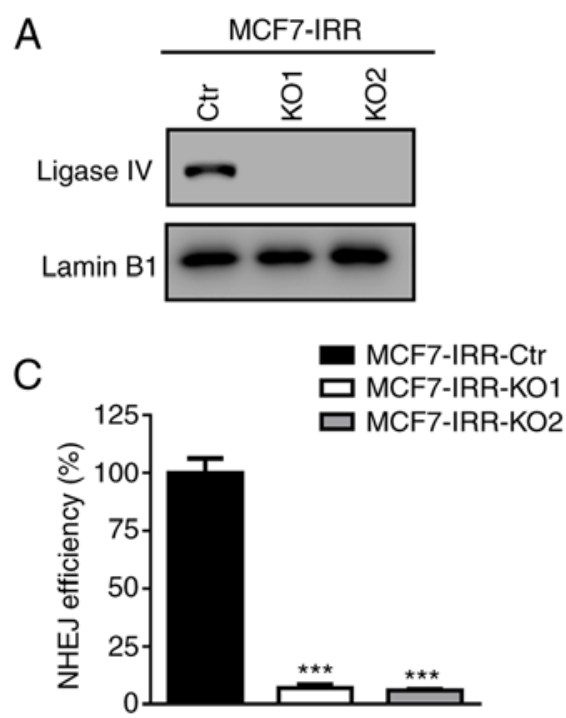

B

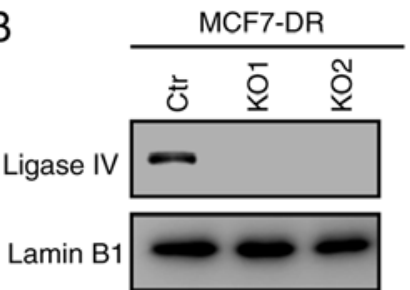

$\mathrm{D}$

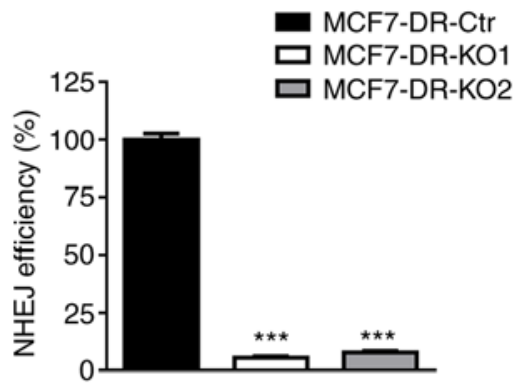

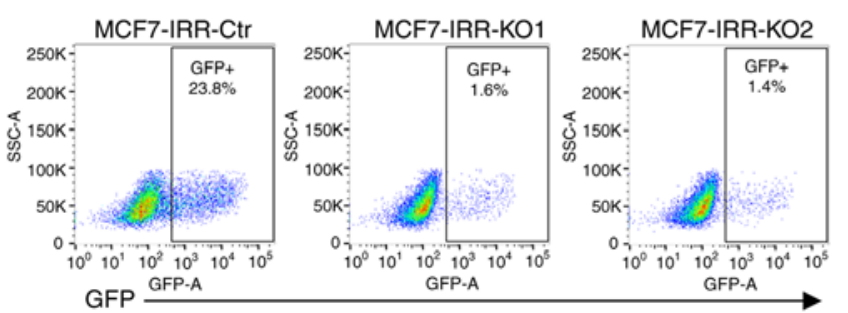
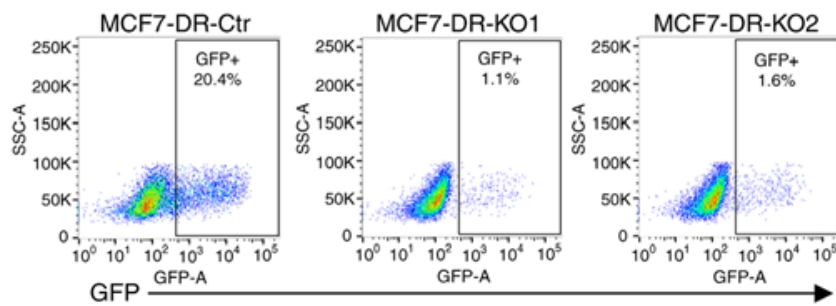

E MCF7-IRR

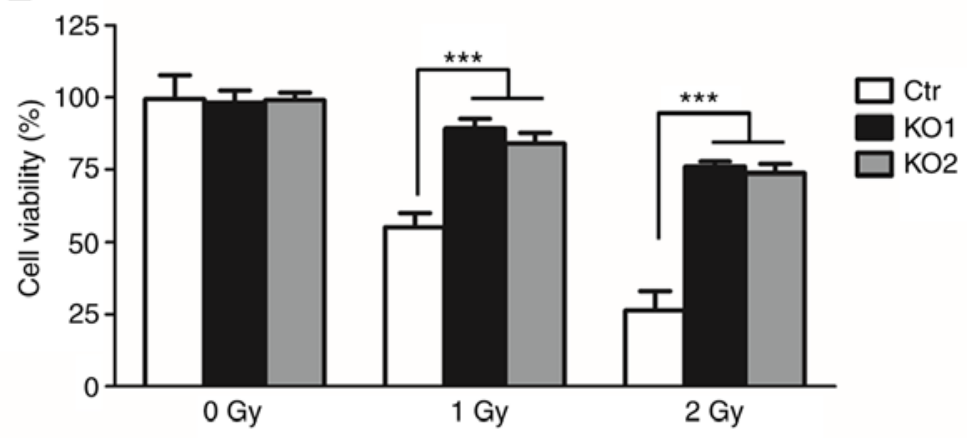

$\mathrm{F}$

MCF-DR

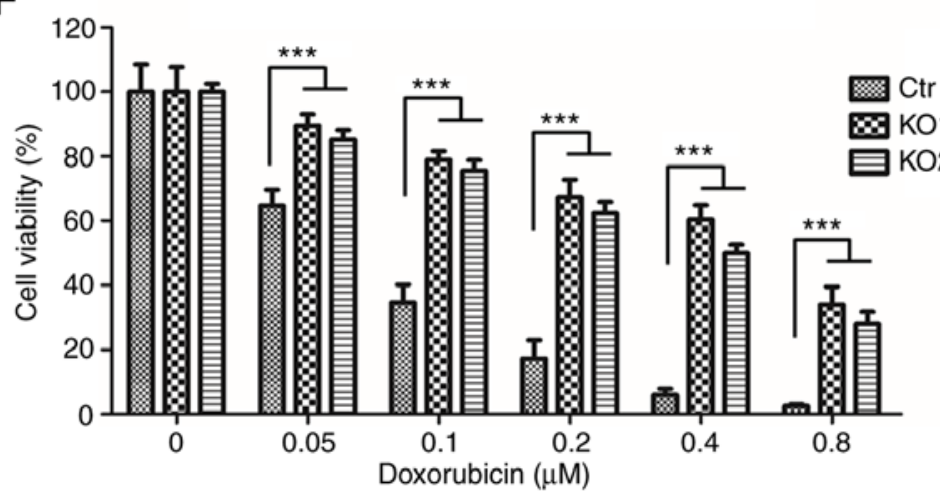

Figure 5. MV overcomes radio- and chemoresistance via inhibition of NHEJ. (A and B) Western blot analysis of DNA ligase IV expression in (A) MCF7-IRR-Ctr, MCF7-IRR-KO1 and MCF7-IRR-KO2 cells and in (B) MCF7-DR-Ctr, MCF7-DR-KO1 and MCF7-DR-KO2 cells. (C) Quantification of GFP generated by NHEJ in MCF7-IRR-Ctr, MCF7-IRR-KO1 and MCF7-IRR-KO2 cells. The GFP level was normalized to that of MCF7-IRR-Ctr cells. ${ }^{* * *} \mathrm{P}<0.001$ vs. Ctr. (D) Quantification of GFP generated by NHEJ in MCF7-DR-Ctr, MCF7-DR-KO1 and MCF7-DR-KO2 cells. The GFP level was normalized to that of MCF7-DR cells. ${ }^{* * *} \mathrm{P}<0.001$ vs. Ctr. (E and F) MV-Edm failed to re-sensitize ligase IV-deficient (E) MCF7-IRR cells to IR and (F) MCF7-DR cells to doxorubicin. MCF7-IRR-Ctr, MCF7-IRR-KO1, MCF7-IRR-KO2, and MCF7-DR-Ctr, MCF7-DR-KO1 and MCF7-DR-KO2 cells were infected with MV-Edm at $0.5 \mathrm{MOI}$ for $24 \mathrm{~h}$ followed by IR and doxorubicin treatment, respectively. Cell viability was evaluated using MTT assay and cells were either normalized to MV-Edm-treated MCF7-IRR-Ctr without IR exposure or MV-Edm-treated MCF7-DR-Ctr with $0 \mu \mathrm{M}$ doxorubicin treatment. ${ }^{* * *} \mathrm{P}<0.001$. MV, measles virus; NHEJ, non-homologous end joining; IR, ionizing radiation; IRR, ionizing radiation resistant; Ctr, control; KO, knockout; DR, doxorubicin resistant; Edm, Edmonston-B; GFP, green fluorescent protein. 
survival decreased by 4.56 -fold at $0.2 \mu \mathrm{M}$ compared with 0 MOI MV-Edm treatment (Fig. 4F). Similar re-sensitization to IR and doxorubicin by MV-Edm was observed in T47D-IRR cells by 3.70-fold at 2 Gy and in T47D-DR cells 3.61-fold at $0.2 \mu \mathrm{M}$ compared with $0 \mathrm{MOI} \mathrm{MV}-\mathrm{Edm}$ treatment (Fig. 4G and H). To further elucidate the mechanism underlying IR- and doxorubicin-induced cell death, the caspase-3/7 activity assay was used to determine apoptosis following IR or doxorubicin treatment in the absence or presence of MV-Edm. As presented in Fig. S3, combination treatment with MV-Edm and IR or doxorubicin induced a significant dose-dependent increase of caspase-3/7 activation in resistant cells. These results suggested that $\mathrm{MV}$-Edm may serve a promising role as a re-sensitizing agent for radio- or chemotherapy.

MV overcomes radio- and chemoresistance by inhibiting NHEJ. To determine whether MV-Edm may overcome IR or doxorubicin resistance by impeding the NHEJ pathway, NHEJ-deficient cells were constructed by knocking down its key factor, ligase IV. Using a commercially available CRISPR/cas9 plasmid with a ligase IV guiding sequence, ligase IV-deficient MCF7-IRR and MCF7-DR cells [MCF7-IRR-knockout (KO)1, MCF7-IRR-KO2, MCF7-DR-KO1 and MCF7-DR-KO2] were generated. Western blot analysis of DNA ligase IV demonstrated that there was no detectable ligase IV protein expression in the $\mathrm{KO}$ cells compared with that in the parental cell lines transfected with CRISPR/cas9-Ctr (Fig. 5A and B).

To verify the ligase IV deficient cell lines, NHEJ efficiency was compared between the ligase IV-KO and the control cell lines. MCF7-IRR-KO1 and MCF7-IRR-KO2 exhibited near complete loss of NHEJ compared with that in the MCF7-IRR-Ctr cells (Fig. 5C). As demonstrated in Fig. 5D, MCF7-DR-KO1 and MCF7-DR-KO2 were also NHEJ-deficient. Therefore, NHEJ-deficient radio- and chemoresistant cells were successfully constructed to elucidate the re-sensitizing mechanism of MV-Edm.

To verify the role of the NHEJ pathway in the re-sensitization to IR or doxorubicin induced by MV-Edm, the cell viability in MCF7-IRR-Ctr and MCF7-IRR-KO cells was investigated. As presented in Fig. 5E, following infection with 0.5 MOI MV-Edm, both MCF7-IRR-KO cell lines exhibited a significant increase in IR resistance compared with that in the MCF7-IRR-Ctr cells. These results suggested that the effects of MV-Edm on IR resistance in breast cancer cells required efficient NHEJ.

Subsequently, MCF7-DR-Ctr, MCF7-DR-KO1 and MCF7-DR-KO2 cell lines were infected with $0.5 \mathrm{MOI}$ $\mathrm{MV}-\mathrm{Edm}$, and cell viability was measured following doxorubicin treatment. Consistent with the results presented in Fig. 5E, MCF7-DR-KO cells were more resistant to doxorubicin compared with MCF7-DR-Ctr cells (Fig. 5F). Thus, these results demonstrated that the MV-Edm-induced re-sensitization to IR and doxorubicin was achieved by inhibition of NHEJ.

\section{Discussion}

Despite the advances in surgery, chemo- and radiotherapy, treatment of breast cancer remains a clinical and scientific challenge due to chemo- and radioresistance (31). However, alternative treatments or methods to overcome resistance are limited.
Therefore, identification of novel approaches and understanding the mechanism of resistance are essential to improve breast cancer therapy.

MV has been recognized as a promising system to develop potent and safe anticancer therapies (32). Infecting patients with a replicating virus may raise a number of safety issues, such as immune suppression (33); however, attenuated MV virotherapy is less active compared with a replicating virus and tumor-selective by interacting with the MV CD46 receptor, which is upregulated in tumor cells $(34,35)$. By proteolytically creating inactive $\mathrm{C} 3 \mathrm{~b}$ and $\mathrm{C} 4 \mathrm{~b}$ complement proteins, upregulated CD46 prevents the tumor cells from complement lysis (36). Consistently, CD46 expression is negatively associated with prognosis in breast cancer, as well as in other types of cancer, such as ovarian and prostate cancer, multiple myeloma and colorectal cancer (37-41). In particular, patients with CD46-positive breast tumors present with a significantly shorter progression-free and overall survival time compared with those with CD46-negative tumors (37). A genetic study of nectin-4, which is another MV receptor upregulated in breast cancer and glioblastoma, demonstrated that downregulation of nectin- 4 by microRNA(miR)-31 and miR-128 markedly impaired the infection rate of MV-Edm in vitro and in vivo (42).

Attenuated MV is non-persistent and non-transmissible, which further supports the application and refinement of MV in the treatment of various types of cancer, such as ovarian cancer and recurrent or refractory multiple myeloma (43-47). The safety of MV-Edm derivatives has been demonstrated in clinical trials with minimal toxicity (48). Ovarian cancer and glioblastoma multiforme were first selected to investigate the preclinical toxicity of MV-Edm in 2002 and 2003, respectively $(44,49)$. Subsequent studies have used suitable animal models, such as the interferon type I receptor-deficient CD46 Ge mouse, Rhesus macaques and squirrel monkeys, which are permissive to MV-Edm, to elucidate dosing strategies and routes of administration, and no virus-associated toxicity was observed (50-52). The first phase I clinical trial of the MV vaccine was conducted in Switzerland in cutaneous patients with T-cell lymphoma (53). Even with a low dose of MV, 4/5 patients exhibited partial regression with no dose-limiting toxicity (53). This promising study resulted in subsequent multiple phase I/II clinical trials in ovarian cancer (NCT02364713 and NCT02068794) $(8,54)$, glioblastoma multiforme (NCT00390299) (8), multiple myeloma (NCT00450814) (55), mesothelioma (NCT01846091) (56), squamous cell head and neck cancer (NCT02192775) (57), breast cancer (NCT01503177) (58) and malignant peripheral nerve sheath tumors, (NCT02700230) (59). Recombinant MV-Edm derivatives, including MV-carcinoembryonic antigen and MV-thyroidal sodium iodide symporter, induced a 2-fold increase of median overall survival rate with no dose-limiting toxicity in a total of 37 patients with ovarian cancer (60). Similar low toxicity was observed in trials involving glioblastoma multiforme and multiple myeloma (60). Despite the verified safety profile of the MV strains, there are several difficulties for measles-based therapeutics, including immunity to MV and MV-triggered immune responses $(61,62)$. Various strategies have been proposed and validated to protect virus infusion and increase safety, such as cell-based delivery vehicles and combination therapy with immunosuppressant drugs (60). 
The results of the present study confirmed that MV-Edm inhibited breast cancer cell viability. Notably, the results demonstrated that the viral infection affected the efficiency of the NHEJ pathway in breast cancer cells. Association between high NHEJ efficiency and low responsiveness to cancer treatments has been observed in various types of cancer, including ovarian cancer, cervical carcinoma, head and neck squamous cell carcinoma and lung cancer (63). In breast cancer cells, NHEJ efficiency is not significantly higher compared with that in normal mammary epithelial cells (64). However, increases in the interaction between $\mathrm{Ku}$ and DNA-PKcs proteins have been demonstrated to occur via non-coding RNA LINP1, which results in efficient NHEJ, thus enhancing radio- and chemoresistance in triple-negative breast cancer cells (65). The results of the present study demonstrated that, mechanistically, MV-Edm attenuated NHEJ by downregulating 53BP1 expression and assembly of the NHEJ complex in resistant cells. Since abnormal DNA repair is associated with chemoand radioresistance, DR and IRR breast cancer cell lines were constructed to evaluate the potential of attenuated MV in overcoming treatment resistance. The results demonstrated that inhibition of NHEJ by MV-Edm significantly improved the sensitivity of resistant breast cancer cells to doxorubicin and IR therapy.

The present study provides a novel approach for re-sensitizing breast cancer cells to chemo- and radiotherapy, and provides other researchers with the knowledge to investigate whether MV overcomes chemoresistance in various subtypes of breast cancer, as well as in other types of cancer. In addition, it is also important to elucidate whether MV acts in synergy with other DNA-damaging targeting agents.

In conclusion, the results of the present study demonstrated that MV-Edm inhibited the NHEJ pathway in breast cancer cells. To the best of our knowledge, this is the first report that associates the DNA DSB repair pathway with MV-Edm infection. Mechanistically, MV-Edm impeded 53BP1 expression and NHEJ factor assembly on DNA. Notably, MV-Edm may re-sensitize IRR or DR breast cancer cells by impairing NHEJ efficiency. Therefore, MV-Edm is a potential treatment option in radio- and chemotherapy in breast cancer.

\section{Acknowledgements}

Not applicable.

\section{Funding}

This study was supported by the National Natural Science Foundation of China (grant no. 81601756), the China Postdoctoral Science Foundation (grant no. 2017M611328), the Jilin Provincial Department of Education 'Thirteenth Five-Year Plan' Science and Technology Research Planning Project (grant no. JJKH20170830KJ) and Jilin University Bethune Project B (grant no. 2015323).

\section{Availability of data and materials}

All data generated or analyzed during this study are included in this published article. Additional data are available from the corresponding author on reasonable request.

\section{Authors' contributions}

BY, JS and XX conceived and designed the experiments. BY, DZ and ZS performed the experiments and analyzed the data. JS wrote the manuscript and provided the funding. XX reviewed, revised and approved the manuscript. All authors read and approved the final manuscript.

\section{Ethics approval and consent to participate}

Not applicable.

\section{Patient consent for publication}

Not applicable.

\section{Competing interests}

The authors declare that they have no competing interests.

\section{References}

1. Enders G: Paramyxoviruses. In: Medical Microbiology. Baron S (ed). 4th edition. University of Texas Medical Branch at Galveston, Galveston, TX, 1996.

2. Enders JF and Peebles TC: Propagation in tissue cultures of cytopathogenic agents from patients with measles. Proc Soc Exp Biol Med 86: 277-286, 1954.

3. Grote D, Russell SJ, Cornu TI, Cattaneo R, Vile R, Poland GA and Fielding AK: Live attenuated measles virus induces regression of human lymphoma xenografts in immunodeficient mice. Blood 97: 3746-3754, 2001

4. Chen A, Zhang Y, Meng G, Jiang D, Zhang H, Zheng M, Xia M, Jiang $\mathrm{A}, \mathrm{Wu} \mathrm{J}$, Beltinger $\mathrm{C}$ and Wei J: Oncolytic measles virus enhances antitumour responses of adoptive CD8+NKG2D+ cells in hepatocellular carcinoma treatment. Sci Rep 7: 5170, 2017.

5. Msaouel P, Opyrchal M, Domingo Musibay E and Galanis E: Oncolytic measles virus strains as novel anticancer agents. Expert Opin Biol Ther 13: 483-502, 2013.

6. Allen C, Opyrchal M, Aderca I, Schroeder MA, Sarkaria JN, Domingo E, Federspiel MJ and Galanis E: Oncolytic measles virus strains have significant antitumor activity against glioma stem cells. Gene Ther 20: 444-449, 2013.

7. Galanis E, Hartmann LC, Cliby WA, Long HJ, Peethambaram PP, Barrette BA, Kaur JS, Haluska PJ Jr, Aderca I, Zollman PJ, et al: Phase I trial of intraperitoneal administration of an oncolytic measles virus strain engineered to express carcinoembryonic antigen for recurrent ovarian cancer. Cancer Res 70: 875-882, 2010.

8. Hutzen B, Raffel C and Studebaker AW: Advances in the design and development of oncolytic measles viruses. Oncolytic Virother 4: 109-118, 2015.

9. Iankov ID, Kurokawa CB, D'Assoro AB, Ingle JN Domingo-Musibay E, Allen C, Crosby CM, Nair AA, Liu MC, Aderca I, et al: Inhibition of the Aurora A kinase augments the anti-tumor efficacy of oncolytic measles virotherapy. Cancer Gene Ther 22: 438-444, 2015.

10. Patel S: Breast cancer: Lesser-known facets and hypotheses. Biomed Pharmacother 98: 499-506, 2018.

11. DeSantis CE, Ma J, Gaudet MM, Newman LA, Miller KD, Goding Sauer A, Jemal A and Siegel RL: Breast cancer statistics, 2019. CA Cancer J Clin 69: 438-451, 2019.

12. Rivera E and Gomez H: Chemotherapy resistance in metastatic breast cancer: The evolving role of ixabepilone. Breast Cancer Res 12 (Suppl 2): S2, 2010.

13. Sun J, Guo Y, Fu X, Wang Y, Liu Y, Huo B, Sheng J and Hu X: Dendrobium candidum inhibits MCF-7 cells proliferation by inducing cell cycle arrest at $\mathrm{G} 2 / \mathrm{M}$ phase and regulating key biomarkers. Onco Targets Ther 9: 21-30, 2015.

14. Cheung-Ong K, Giaever G and Nislow C: DNA-damaging agents in cancer chemotherapy: Serendipity and chemical biology. Chem Biol 20: 648-659, 2013. 
15. Khanna A: DNA damage in cancer therapeutics: A boon or a curse? Cancer Res 75: 2133-2138, 2015.

16. Gao D, Herman JG and Guo M: The clinical value of aberrant epigenetic changes of DNA damage repair genes in human cancer. Oncotarget 7: 37331-37346, 2016.

17. O'Connor MJ: Targeting the DNA damage response in cancer. Mol Cell 60: 547-560, 2015.

18. Cannan WJ and Pederson DS: Mechanisms and consequences of double-strand DNA break formation in chromatin. J Cell Physiol 231: 3-14, 2016.

19. Jeggo PA and Löbrich M: DNA double-strand breaks: Their cellular and clinical impact? Oncogene 26: 7717-7719, 2007.

20. Haber JE: Partners and pathwaysrepairing a double-strand break Trends Genet 16: 259-264, 2000.

21. Rothkamm K, Krüger I, Thompson LH and Löbrich M: Pathways of DNA double-strand break repair during the mammalian cell cycle. Mol Cell Biol 23: 5706-5715, 2003.

22. Hinz JM, Yamada NA, Salazar EP, Tebbs RS and Thompson LH: Influence of double-strand-break repair pathways on radiosensitivity throughout the cell cycle in CHO cells. DNA Repair (Amst) 4: 782-792, 2005.

23. Duprex WP, McQuaid S, Hangartner L, Billeter MA and Rima BK: Observation of measles virus cell-to-cell spread in astrocytoma cells by using a green fluorescent protein-expressing recombinant virus. J Virol 73: 9568-9575, 1999.

24. Ramakrishnan MA: Determination of 50\% endpoint titer using a simple formula. World J Virol 5: 85-86, 2016.

25. McDonald CJ, Erlichman C, Ingle JN, Rosales GA, Allen C, Greiner SM, Harvey ME, Zollman PJ, Russell SJ and Galanis E: A measles virus vaccine strain derivative as a novel oncolytic agent against breast cancer. Breast Cancer Res Treat 99: 177-184, 2006.

26. Guo Y, Fu X, Huo B, Wang Y, Sun J, Meng L, Hao T, Zhao ZJ and $\mathrm{Hu} \mathrm{X}$ : GATA2 regulates GATA1 expression through LSD1-mediated histone modification. Am J Transl Res 8: 2265-2274, 2016.

27. Livak KJ and Schmittgen TD: Analysis of relative gene expression data using real-time quantitative PCR and the 2(-Delta Delta C(T)) method. Methods 25: 402-408, 2001.

28. Guo Y, Fu X, Jin Y, Sun J, Liu Y, Huo B, Li X and Hu X: Histone demethylase LSD1-mediated repression of GATA-2 is critical for erythroid differentiation. Drug Des Devel Ther 9: 3153-3162, 2015.

29. Meng Y, Chen CW, Yung MMH, Sun W, Sun J, Li Z, Li J, Li Z Zhou W, Liu SS, et al: DUOXA1-mediated ROS production promotes cisplatin resistance by activating ATR-Chk1 pathway in ovarian cancer. Cancer Lett 428: 104-116, 2018.

30. Daley JM and Sung P: 53BP1, BRCA1, and the choice between recombination and end joining at DNA double-strand breaks. Mol Cell Biol 34: 1380-1388, 2014.

31. Sledge GW, Mamounas EP, Hortobagyi GN, Burstein HJ, Goodwin PJ and Wolff AC: Past, present, and future challenges in breast cancer treatment. J Clin Oncol 32: 1979-1986, 2014.

32. Russell SJ and Peng KW: Measles virus for cancer therapy. Curr Top Microbiol Immunol 330: 213-241, 2009.

33. Laksono BM, de Vries RD, McQuaid S, Duprex WP and de Swart RL: Measles virus host invasion and pathogenesis. Viruses 8: 210, 2016.

34. Msaouel P, Iankov ID, Dispenzieri A and Galanis E: Attenuated oncolytic measles virus strains as cancer therapeutics. Curr Pharm Biotechnol 13: 1732-1741, 2012.

35. Sugiyama T, Yoneda M, Kuraishi T, Hattori S, Inoue Y, Sato H and Kai C: Measles virus selectively blind to signaling lymphocyte activation molecule as a novel oncolytic virus for breast cancer treatment. Gene Ther 20: 338-347, 2013.

36. Noris $\mathrm{M}$ and Remuzzi G: Overview of complement activation and regulation. Semin Nephrol 33: 479-492, 2013.

37. Maciejczyk A, Szelachowska J, Szynglarewicz B, Szulc R, Szulc A, Wysocka T, Jagoda E, Lage H and Surowiak P: CD46 expression is an unfavorable prognostic factor in breast cancer cases. Appl Immunohistochem Mol Morphol 19: 540-546, 2011.

38. Surowiak P, Materna V,Maciejczyk A,Kaplenko I,Spaczynski M, Dietel M, Lage $\mathrm{H}$ and Zabel M: CD46 expression is indicative of shorter revival-free survival for ovarian cancer patients. Anticancer Res 26: 4943-4948, 2006.

39. Su Y, Liu Y, Behrens CR, Bidlingmaier S, Lee NK, Aggarwal R, Sherbenou DW, Burlingame AL, Hann BC, Simko JP, et al: Targeting CD46 for both adenocarcinoma and neuroendocrine prostate cancer. JCI Insight 3: e121497, 2018.
40. Sherbenou DW, Aftab BT, Su Y, Behrens CR, Wiita A, Logan AC, Acosta-Alvear D, Hann BC, Walter P, Shuman MA, et al: Antibody-drug conjugate targeting CD46 eliminates multiple myeloma cells. J Clin Invest 126: 4640-4653, 2016.

41. Cho YS, Do MH, Kwon SY, Moon C, Kim K, Lee K, Lee SJ, Hemmi S, Joo YE, Kim MS and Jung C: Efficacy of CD46-targeting chimeric Ad5/35 adenoviral gene therapy for colorectal cancers. Oncotarget 7: 38210-38223, 2016.

42. Geekiyanage H and Galanis E: MiR-31 and miR-128 regulates poliovirus receptor-related 4 mediated measles virus infectivity in tumors. Mol Oncol 10: 1387-1403, 2016.

43. Carlson SK, Classic KL, Hadac EM, Dingli D, Bender CE, Kemp BJ and Russell SJ: Quantitative molecular imaging of viral therapy for pancreatic cancer using an engineered measles virus expressing the sodium-iodide symporter reporter gene. AJR Am J Roentgenol 192: 279-287, 2009.

44. Peng KW, TenEyck CJ, Galanis E, Kalli KR, Hartmann LC and Russell SJ: Intraperitoneal therapy of ovarian cancer using an engineered measles virus. Cancer Res 62: 4656-4662, 2002.

45. Shoji K, Yoneda M, Fujiyuki T, Amagai Y, Tanaka A, Matsuda A, Ogihara K, Naya Y, Ikeda F, Matsuda H, Sato H and Kai C: Development of new therapy for canine mammary cancer with recombinant measles virus. Mol Ther Oncolytics 3: 15022, 2016.

46. Russell SJ: Replicating vectors for cancer therapy: A question of strategy. Semin Cancer Biol 5: 437-443, 1994.

47. Delpeut S, Sisson G, Black KM and Richardson CD: Measles virus enters breast and colon cancer cell lines through a PVRL4-mediated macropinocytosis pathway. J Virol 91: e02191-16, 2017

48. Baldo A, Galanis E, Tangy F and Herman P: Biosafety considerations for attenuated measles virus vectors used in virotherapy and vaccination. Hum Vaccin Immunother 12: 1102-1116, 2016.

49. Phuong LK, Allen C, Peng KW, Giannini C, Greiner S, TenEyck CJ, Mishra PK, Macura SI, Russell SJ and Galanis EC: Use of a vaccine strain of measles virus genetically engineered to produce carcinoembryonic antigen as a novel therapeutic agent against glioblastoma multiforme. Cancer Res 63: 2462-2469, 2003.

50. Peng KW, Frenzke M, Myers R, Soeffker D, Harvey M, Greiner S, Galanis E, Cattaneo R, Federspiel MJ and Russell SJ: Biodistribution of oncolytic measles virus after intraperitoneal administration into Ifnar-CD46Ge transgenic mice. Hum Gene Ther 14: 1565-1577, 2003

51. Myers R, Harvey M, Kaufmann TJ, Greiner SM, Krempski JW, Raffel C, Shelton SE, Soeffker D, Zollman P, Federspiel MJ, et al: Toxicology study of repeat intracerebral administration of a measles virus derivative producing carcinoembryonic antigen in rhesus macaques in support of a phase I/II clinical trial for patients with recurrent gliomas. Hum Gene Ther 19: 690-698, 2008.

52. Myers RM, Greiner SM, Harvey ME, Griesmann G, Kuffel MJ, Buhrow SA, Reid JM, Federspiel M, Ames MM, Dingli D, et al: Preclinical pharmacology and toxicology of intravenous MV-NIS, an oncolytic measles virus administered with or without cyclophosphamide. Clin Pharmacol Ther 82: 700-710, 2007.

53. Heinzerling L, Künzi V, Oberholzer PA, Kündig T, Naim H and Dummer R: Oncolytic measles virus in cutaneous T-cell lymphomas mounts antitumor immune responses in vivo and targets interferon-resistant tumor cells. Blood 106: 2287-2294, 2005.

54. Ruf B and Lauer UM: Assessment of current virotherapeutic application schemes: 'hit hard and early' versus 'killing softly'? Mol Ther Oncolytics 2: 15018, 2015.

55. Calton CM, Kelly KR, Anwer F, Carew JS and Nawrocki ST: Oncolytic viruses for multiple myeloma therapy. Cancers (Basel) 10: 198, 2018

56. Robinson S and Galanis E: Potential and clinical translation of oncolytic measles viruses. Expert Opin Biol Ther 17: 353-363, 2017

57. Achard C, Surendran A, Wedge ME, Ungerechts G, Bell J and Ilkow CS: Lighting a fire in the tumor microenvironment using oncolytic immunotherapy. EBioMedicine 31: 17-24, 2018.

58. Galanis E, Atherton PJ, Maurer MJ, Knutson KL, Dowdy SC, Cliby WA, Haluska P Jr, Long HJ, Oberg A, Aderca I, et al: Oncolytic measles virus expressing the sodium iodide symporter to treat drug-resistant ovarian cancer. Cancer Res 75: 22-30, 2015.

59. Robertson KA, Nalepa G, Yang FC, Bowers DC, Ho CY, Hutchins GD, Croop JM, Vik TA, Denne SC, Parada LF, et al: Imatinib mesylate for plexiform neurofibromas in patients with neurofibromatosis type 1: A phase 2 trial. Lancet Oncol 13: $1218-1224,2012$ 
60. Msaouel P, Opyrchal M, Dispenzieri A, Peng KW, Federspiel MJ, Russell SJ and Galanis E: Clinical trials with oncolytic measles virus: Current status and future prospects. Curr Cancer Drug Targets 18: 177-187, 2018

61. Russell SJ, Federspiel MJ, Peng KW, Tong C, Dingli D Morice WG, Lowe V, O'Connor MK, Kyle RA, Leung N, et al: Remission of disseminated cancer after systemic oncolytic virotherapy. Mayo Clin Proc 89: 926-933, 2014.

62. Gauvrit A, Brandler S, Sapede-Peroz C, Boisgerault N, Tangy F and Gregoire M: Measles virus induces oncolysis of mesothelioma cells and allows dendritic cells to cross-prime tumor-specific CD8 response. Cancer Res 68: 4882-4892, 2008.
63. Sishc BJ and Davis AJ: The role of the core non-homologous end joining factors in carcinogenesis and cancer. Cancers (Basel) 9: 81, 2017.

64. Mao Z, Jiang Y, Liu X, Seluanov A and Gorbunova V: DNA repair by homologous recombination, but not by nonhomologous end joining, is elevated in breast cancer cells. Neoplasia 11: 683-691, 2009.

65. Lees-Miller SP, Beattie TL and Tainer JA: Noncoding RNA joins $\mathrm{Ku}$ and DNA-PKcs for DNA-break resistance in breast cancer. Nat Struct Mol Biol 23: 509-510, 2016. 